\title{
Monitoring Perparkiran Mobil Berbasis Sensor Ultrasonik dan Mikrokontroller ESP8266
}

\author{
Dahlia Nur ${ }^{1, a}$, Yori Putra Pradana ${ }^{1, b}$, Sahbuddin Abdul Kadir ${ }^{1, c}$ \\ ${ }^{1}$ Teknik Elektro, Politeknik Negeri Ujung Pandang, Jalan Perintis Kemerdekaan KM.10 Tamalanrea, Makassar 90245 \\ adahlia@poliupg.ac.id \\ byoriputrapradana@gmail.com \\ csahbuddin.ak@poliupg.ac.id
}

\begin{abstract}
The number of motorized vehicles in Indonesia is increasing rapidly every year. Based on data from the Central Statistics Agency (BPS) in 2017, the number of motorized vehicles with Passenger Car vehicles reached 15,493,068 units. The number has increased compared to 2016 amounted to $14,580,666$ units. The increase as the number of motorized vehicles has an impact of the availability of parking lots in a number of locations. Every driver who will park the vehicle wants to get the location / lot of the parking lot as soon as possible. However, the unavailability of parking capacity information in a parking area causes the user to go around first to get an unload parking space, if the parking lot is full, the user even has to go back out because he did not get a parking space. This study designed and built an ESP8266 microcontroller and PING ultrasonic sensor provided information about the availability of parking lots were still unoccupied in this monitoring system. It is hoped can improve the efficiency of parking users who are looking for vacant parking lots and make it easier for parking admins in parking monitoring management. The results showed that the monitoring system that was built could provide information about the availability of empty parking lots and integrated databases to store vehicle owner information based on parking cards. Parking lot information is included on the parking card given to users entering the parking area.
\end{abstract}

Keywords- Monitoring, Parking Lot, Microcontroller ESP8266, Ultrasonic Sensor PING

\footnotetext{
Abstrak - Pertambahan jumlah kendararan bermotor di Indonesia setiap tahun meningkat pesat. Berdasarkan data Badan Pusat Statistik (BPS) tahun 2017, angka kendaraan bermotor dengan jenis kendaraan Mobil Penumpang mencapai 15.493.068 unit. Jumlah tersebut mengalami peningkatan dibandingkan dengan tahun 2016 sebesar 14.580 .666 unit. Peningkatan jumlah kendaraan bermotor berdampak pada ketersediaan lahan parkir di sejumlah lokasi. Setiap pengendara yang akan memarkirkan kendaraanya menginginkan untuk mendapatkan lokasi/lot parkir yang kosong secepatnya. Namun tidak tersedianya informasi kapasitas parkir pada suatu area parkir menyebabkan pengguna harus berkeliling terlebih dahulu untuk mendapatkan tempat parkir yang kosong, apabila lahan
}

parkir penuh pengguna bahkan harus keluar kembali karena tidak mendapatkan tempat parkir. Penelitian ini merancang dan membangun suatu alat mikrokontroller ESP8266 dan sensor ultrasonik PING yang memberikan informasi terhadap ketersediaan lot parkir yang masih kosong. Dengan adanya sistem monitoring ini diharapkan dapat meningkatkan efisiensi dari pengguna parkir yang mencari lot parkir yang kosong serta memudahkan admin parkir dalam manajemen monitoring perparkiran. Hasil penelitian menunjukkan bahwa sistem monitoring yang telah dibangun mampu memberikan informasi terhadap ketersediaan lot parkir yang kosong dan terintegrasi database untuk menyimpan informasi pemilik kendaraan berdasarkan kartu parkir. Informasi lot parkir di cantumkan pada kartu parkir yang diberikan kepada user yang memasuki area parkir.

Kata Kunci- Monitoring, Perparkiran, Mikrokontroller ESP8266, Sensor Ultrasonik PING

\section{Pendahuluan}

Pertambahan jumlah kendararan bermotor di Indonesia setiap tahun meningkat pesat. Berdasarkan data Badan Pusat Statistik (BPS) tahun 2017, angka kendaraan bermotor dengan jenis kendaraan Mobil Penumpang mencapai 15.493.068 unit. Jumlah tersebut mengalami peningkatan dibandingkan dengan tahun 2016 sebesar 14.580.666 unit [1]. Peningkatan jumlah kendaraan bermotor berdampak pada ketersediaan lahan parkir di sejumlah lokasi [2].

Kebijakan pemerintah untuk mengurangi adanya parkir di area jalan dilakukan dengan mengharuskan pusat-pusat kegiatan bisnis (business district), rumah sakit, perkantoran baik swasta maupun pemerintah menyediakan suatu ruang parkir yang cukup (memenuhi standar). Penyediaan ruang parkir yang cukup pada 
pusat-pusat kegiatan bisnis (mall) umumnya dalam bentuk lahan parkir bertingkat [3].

Setiap pengendara yang akan memarkirkan kendaraanya menginginkan untuk mendapatkan lokasi/lot parkir yang kosong secepatnya. Namun tidak tersedianya informasi kapasitas parkir pada suatu area parkir menyebabkan pengguna harus berkeliling terlebih dahulu untuk mendapatkan tempat parkir yang kosong, apabila lahan parkir penuh pengguna bahkan harus keluar kembali karena tidak mendapatkan tempat parkir. Untuk itu perlu dilakukan upaya pengembangan sistem monitoring perparkiran yang menerapkan peralatan sensor sehingga informasi lot parkir yang kosong pada area parkir dapat oleh pengguna cepat dan akurat, hal ini akan sangat membantu pengguna dalam proses pencarian tempat parkir.

Pada penelitian sebelumnya oleh Rudi dkk, 2017 [4], dengan judul Rancang Bangun Prototype Sistem Smart Parking Berbasis Arduino Dan Pemantauan Melalui Smartphone. Telah merancang Smart Parking yang dapat menginformasikan dan mengarahkan pengendara mobil ke area parkir yang kosong. Lahan parkir yang dijadikan sebagai objek penelitiannya terdiri dari beberapa lokasi parkir dengan kapasitas beberapa kendaraan. Pada perancangan ini memiliki beberapa bagian umum yang digunakan, yaitu sensor ultrasonik, Arduino Mega, PC/laptop, LCD (Liquid Cristal Display) dan IoT (Internet Of Things). Penelitian menunjukkan bahwa LCD akan menampilkan beberapa slot parkir yang sudah terisi dan beberapa lagi slot parkir yang kosong dan pemantauan melalui Smartphone dengan menggunakan aplikasi Blynk.

Berdasarkan kondisi diatas maka dibangun suatu alat mikrokontroller yang memberikan informasi terhadap ketersediaan lot parkir yang masih kosong. Ketersediaan lot parkir tersebut di monitoring oleh admin parkir melalui sistem monitoring perparkiran. Dengan adanya sistem monitoring ini diharapkan dapat meningkatkan efisiensi dari pengguna parkir yang mencari lot parkir yang kosong serta memudahkan admin parkir dalam manajemen monitoring perparkiran.

\section{Kajian Literatur}

\section{A. Monitoring}

Monitoring adalah pemantauan yang dapat memberikan informasi tentang status dan kecenderungan bahwa pengukuran dan evaluasi yang diselesaikan berulang dari waktu ke waktu, pemantauan umumnya dilakukan untuk tujuan tertentu, untuk memeriksa terhadap proses berikut objek atau untuk mengevaluasi kondisi atau kemajuan menuju tujuan hasil manajemen atas efek tindakan dari beberapa jenis antara lain tindakan untuk mempertahankan manajemen yang sedang berjalan [5].

\section{B. Parkir}

Kendaraan tidak mungkin bergerak terus-menerus, akan ada waktunya kendaraan itu harus berhenti, baik itu bersifat sementara maupun bersifat lama atau biasa yang disebut parkir. Menurut Martadipura parkir adalah suatu keadaan dimana suatu kendaraan yang bersifat sementara ditinggalkan oleh pengemudinya [6].

\section{Mikrokontroller}

Mikrokontroller merupakan sebuah sistem komputer fungsional yang di letakkan dalam papan elektronik yang berukuran mikro atau kecil. Di dalam mikrokontroller terdapat sebuah prosesor, memori, serta komponen input dan output. Dengan begitu, mikrokontroller adalah suatu alat elektronika digital yang memiliki input serta output yang kendalinya dapat diprogram ulang dengan suatu cara khusus. Ada banyak pilihan mikrokontroller yang telah terdapat modul jaringan agar dapat langsung terhubung ke jaringan internet sehingga dapat di implimentasikan untuk membuat peralatan berbasis IoT/WSN, contohnya NodeMCU ESP8266.

\section{NodeMCU ESP8266}

Merupakan single board microcontroller yang ditenagai memori $128 \mathrm{kBytes}$, tempat penyimpanan 4Mbytes, dan bersumber daya dari USB. Mikrokontroller ini memiliki modul $\mathrm{WiFi}$ dan firmware menggunakan bahasa pemrograman LUA atau Arduino IDE [7]. 


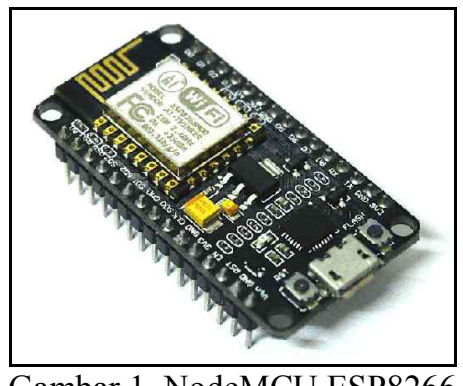

Gambar 1. NodeMCU ESP8266

\section{Sensor Ultrasonik PING Parallax}

Sensor ultrasonik adalah sebuah sensor yang mengubah besaran fisis (bunyi) menjadi besaran listrik. Pada sensor ini gelombang ultrasonik dibangkitkan melalui sebuah benda yang disebut piezoelektrik. Piezoelektrik ini akan menghasilkan gelombang ultrasonik dengan frekuensi $40 \mathrm{kHz}$ ketika sebuah osilator diterapkan pada benda tersebut.

Sensor ultrasonik ini dapat mengukur jarak antara 3 $\mathrm{cm}$ sampai $300 \mathrm{~cm}$. Keluaran dari modul sensor ultrasonik PING ini berupa pulsa yang lebarnya merepresentasikan jarak. Lebar pulsanya yang dihasilkan modul sensor ultrasonik ini bervariasi dari $115 \mathrm{uS}$ sampai 18,5 mS. Secara prinsip modul sensor ultrasonik ini terdiri dari sebuah chip pembangkit sinyal $40 \mathrm{kHz}$, sebuah speaker ultrasonik dan sebuah mikropon ultrasonik. Speaker ultrasonik mengubah sinyal $40 \mathrm{kHz}$ menjadi suara sementara mikropon ultrasonik berfungsi untuk mendeteksi pantulan suaranya [8][9]. Bentuk sensor ultrasonik diperlihatkan pada Gambar 2.

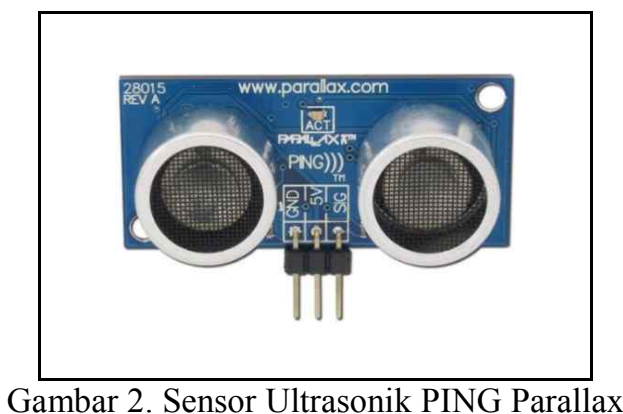

\section{E. Protokol MQTT}

Protokol MQTT merupakan sebuah protokol pertukaran pesan dengan model publish/subscribe yang sederhana dan ringan serta didesain untuk perangkat yang memiliki kemampuan terbatas dan bandwidth yang kecil, latency tinggi, atau jaringan yang tidak andal. Prinsip desain MQTT adalah untuk meminimalisasi bandwidth jaringan dan kebutuhan resource perangkat dan tetap menjamin keandalan dan beberapa tingkat jaminan tersampaikannya sebuah pesan. Prinsip inilah yang membuat protokol ini ideal untuk diaplikasikan pada komunikasi machine-to-machine (M2M) atau Internet of Things dan untuk aplikasi mobile dimana bandwidth dan kapasitas baterai terbatas.

Pertukaran pesan dengan model publish/subscribe pada MQTT merupakan alternatif dari model clientserver, dimana sebuah client (publisher/subscriber) berkomunikasi langsung dengan sebuah endpoint lainnya pada sebuah topik melalui sebuah broker yang bertugas melakukan penyaringan pesan dan mendistribusikannya [10].

\section{Metode Penelitian}

\section{A. Arsitektur Sistem}

Arsitektur sistem merupakan penggambaran umum untuk sistem yang akan dibuat. Pada Gambar 3 menunjukkan model perancangan arsitektur sistem monitoring perparkiran yang dibuat berdasarkan dari hasil analisa kebutuhan.

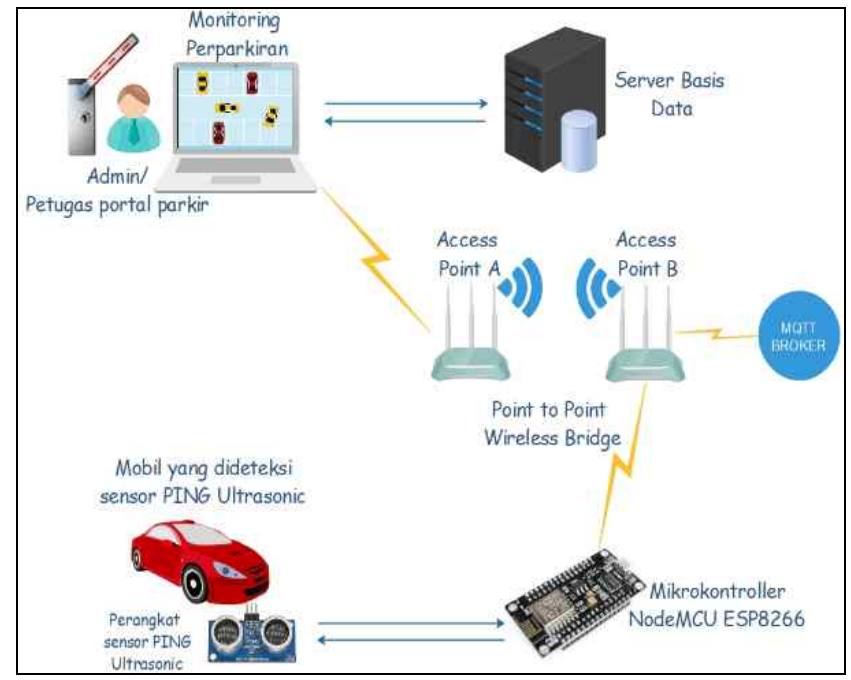

Gambar 3. Arsitektur Sistem

\section{B. Activity Diagram}

Activity Diagram merupakan diagram yang menggambarkan aliran kerja atau aktivitas dari sebuah sistem atau proses bisnis bukan apa yang dilakukan aktor, jadi aktivitas yang dapat dilakukan oleh sistem. 


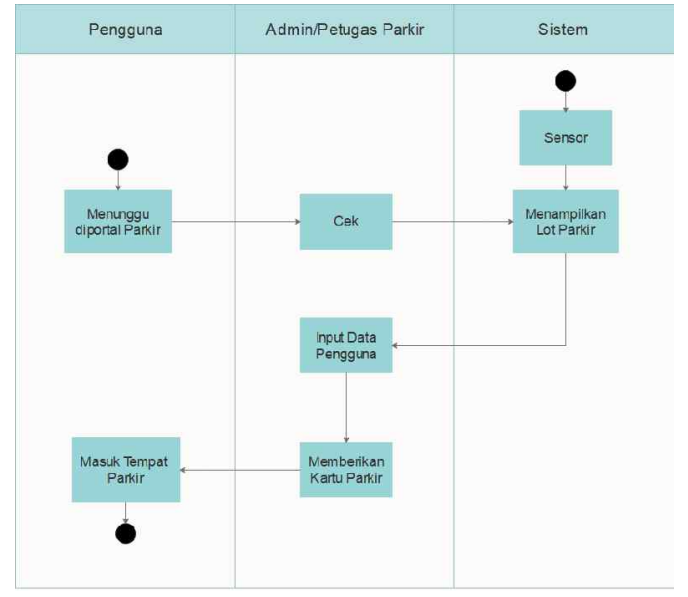

Gambar 4. Diagram Activity

\section{Flowchart}

Flowchart adalah suatu bagan dengan simbol-simbol tertentu yang menggambarkan urutan proses (intruksi) dengan proses lainnya dalam suatu program. Flowchart pada sistem monitoring perparkiran terdapat pada Gambar 5.

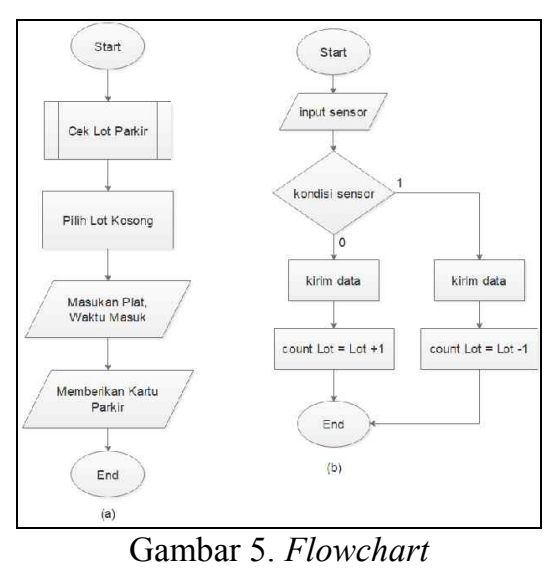

D. Rangkaian Mikrokontroller dan Sensor Ultrasonik

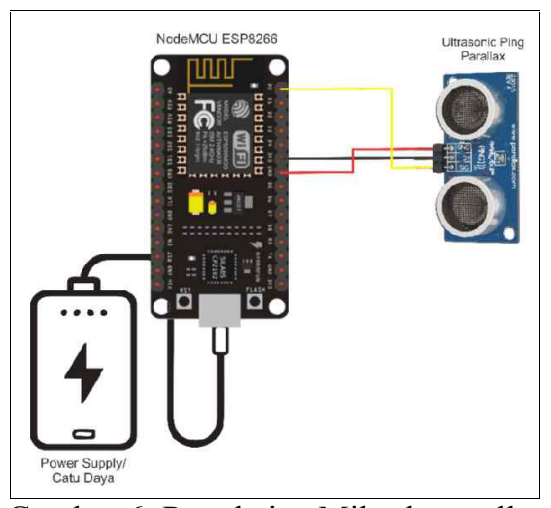

Gambar 6. Rangkaian Mikrokontroller dan Sensor Ultrasonik
E. Flowchart Rangkaian Mikrokontroller dan Sensor Ultrasonik

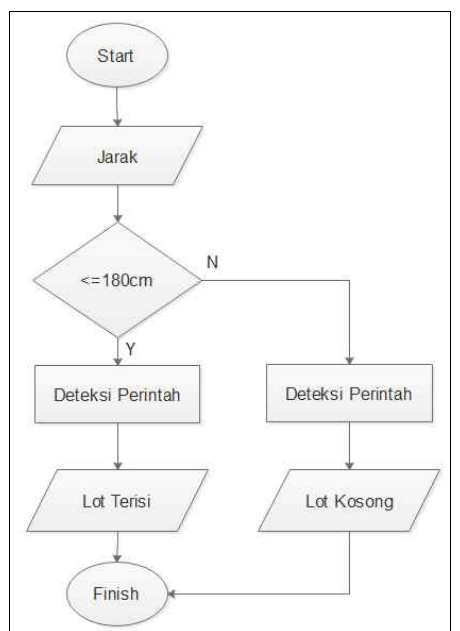

Gambar 7. Flowchart Rangkaian Mikrokontroller dan Sensor Ultrasonik

\section{Hasil dan Pembahasan}

Hasil yang diperoleh dari penelitian ini yaitu monitoring perparkiran mobil menggunakan sensor ultrasonik berbasis wireless. Sistem monitoring ini terintegrasi pada prototipe lot parkir melalui koneksi wireless dengan menggunakan metode bridge antar access point untuk memperluas sinyal, sehingga admin/pertugas portal parkir dapat melakukan monitoring perparkiran.

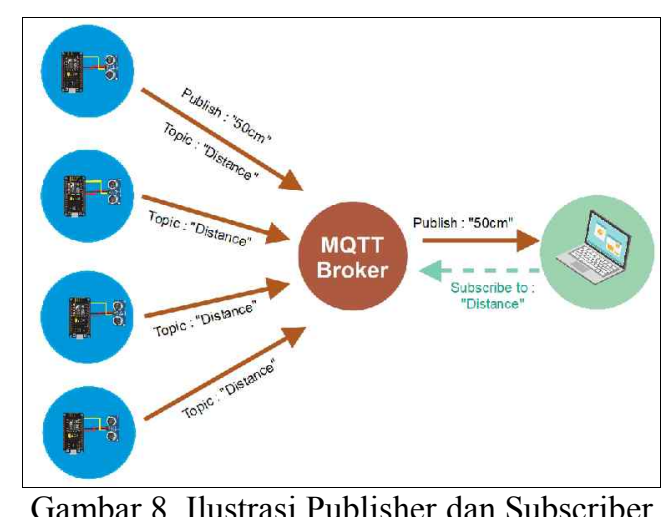

Gambar 8 diatas menggambarkan Ilustrasi Publisher dan Subscriber dalam protokol MQTT. Mikrokontroller ESP8266 mem-publish sebuah pesan dengan jarak sensor $50 \mathrm{~cm}$ dan "Distance" sebagai topic. Broker menerima pesan yang di-publish oleh publisher, dan meneruskan topic "Dinstance" ke Laptop/computer monitoring. 
Berdasarkan perancangan tersebut, maka telah dilakukan implementasi serta pengujian sistem yang meliputi pengujian fungsionalitas dan pengujian kinerja.

\section{A. Implementasi}

Implementasi pada monitoring perparkiran mobil menggunakan sensor ultrasonik berbasis wireless ini merupakan tampilan monitoring, mulai dari pengecekan lot parkir yang kosong, pemasukan data pengguna, hingga monitoring perparkiran oleh admin.

1) Halaman Utama

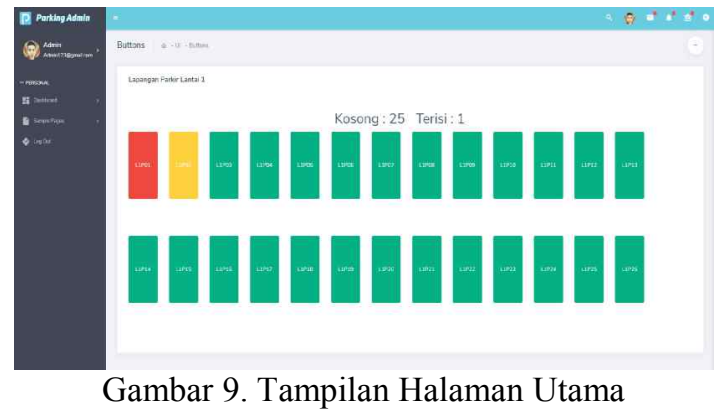

Gambar 9 merupakan halaman utama yang menampilkan jumlah lot parkir yang kosong maupun lot parkir yang sedang terisi oleh kendaraan. Warna pada lot parkir terbagi menjadi 3 warna yaitu hijau, merah, dan kuning.

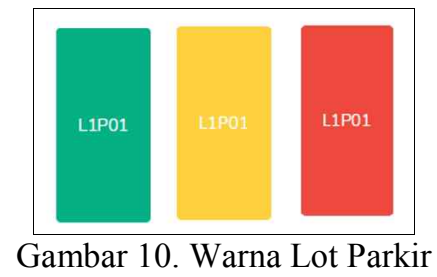

Pada saat kondisi lot parkir berwarna hijau berarti lot tersebut sedang kosong. Pada saat kondisi lot parkir berwarna kuning berarti pemilik kendaraan telah menerima kartu parkir dari admin dan segera menuju ke lot parkir, sehingga admin mengetahui lot parkir mana yang kartu parkirnya telah tercetak namun kendaraan belum terdeteksi oleh sensor, sedangkan jika kondisi lot parkir berwarna merah maka lot parkir tersebut telah terisi oleh kendaraan.

2) Halaman Pemasukan Plat Nomor Kendaraan

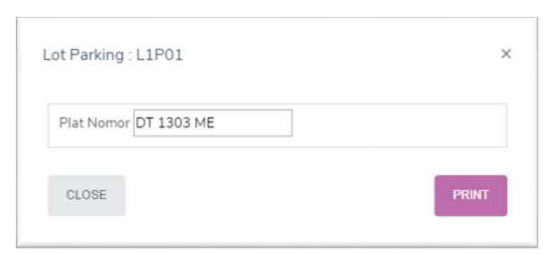

Gambar 11. Halaman Pemasukan Plat Nomor Kendaraan
Gambar 11 merupakan halaman pemasukan plat nomor kendaran berfungsi untuk memasukkan nomor plat kendaraan. Ketika admin memilih lot yang kosong sistem meminta input plat nomor kendaraan dari pengguna perparkiran.

3) Tampilan Cetak Kartu Parkir

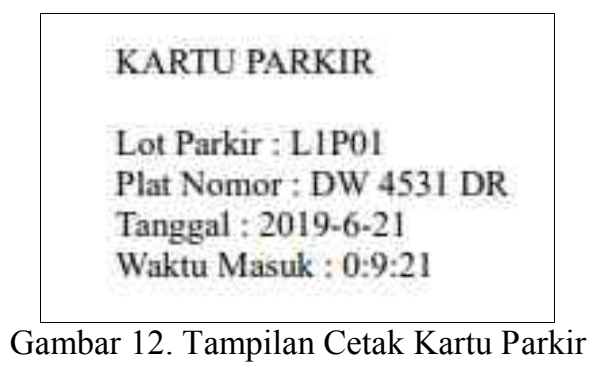

\section{B. Pengujian Fungsionalitas}

Pengujian fungsionalitas meliputi pengujian monitoring perparkiran, pengelolaan database, melihat data kendaraan masuk, serta pengujian prototipe lot parkir.

1) Pengujian Fungsionalitas Monitoring Perparkiran

Pengujian fungsionalitas monitoring perparkiran dilakukan dengan melihat jumlah lot parkir yang terisi maupun yang kosong, dan memilih salah satu lot parkir yang kosong dan memasukkan nomor plat kendaraan pengguna.

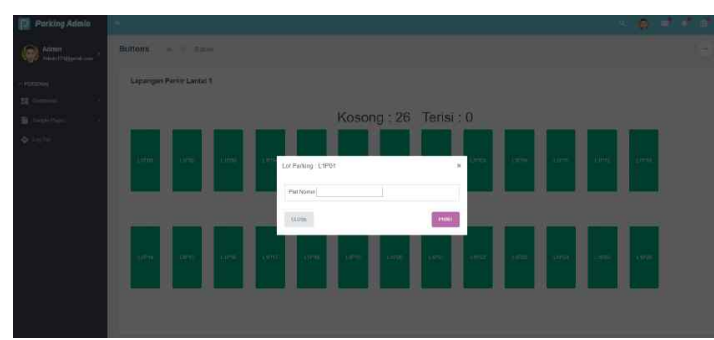

Gambar 13. Pemasukan Plat Nomor Kendaraan

Gambar 13 menunjukkan bahwa admin telah memlih lot yang kosong dan memasukkan nomor plat kendaraan yang telah menunggu di portal parkir. Pada tabel_sensor kolom terisi kosong di database telah ter-update dengan angka "2" berarti lot parkir L1P01 akan terisi mobil yang telah mendapatkan kartu parkir dapat dilihat pada Gambar 14.

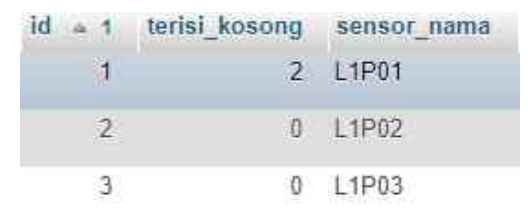

Gambar 14. Terisi_kosong ter-update 


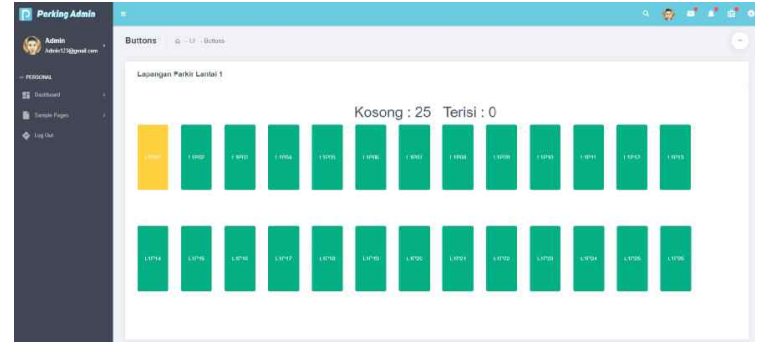

Gambar 15. Tampilan Monitoring Perparkiran (lot berwarna kuning)

Gambar 15 menunjukkan bahwa ketika admin telah mencetak kartu parkir pengguna pada lot parkir L1P01 maka warna pada lot parkir L1P01 berubah dari hijau menjadi kuning dan lot parkir yang kosong secara otomatis berkurang 1, yang sebelumnya jumlah lot parkir sebanyak 26 lot parkir menjadi 25 lot parkir yang kosong.

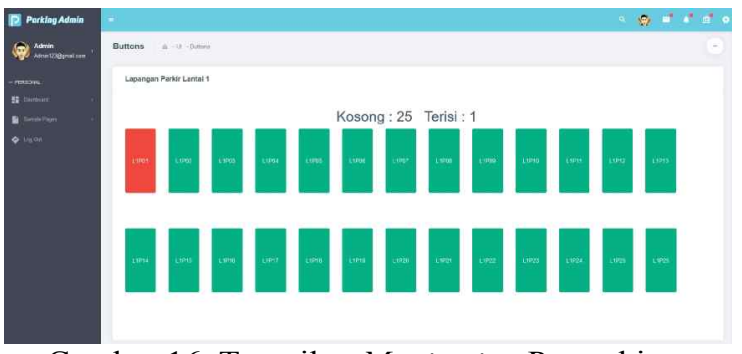

Gambar 16. Tampilan Monitoring Perparkiran (lot berwarna merah)

Gambar 16 menunjukkan bahwa warna pada lot parkir L1P01 berubah dari kuning menjadi hijau dan pada tabel_sensor kolom terisi_kosong di database telah ter-update dengan angka "1", berarti lot parkir L1P01 telah terisi kendaraan yang dapat dilihat pada Gambar 17.

\begin{tabular}{|ccc|}
\hline id $\Delta \mathbf{A}_{1}$ & terisi_kosong & sensor_nama \\
\hline 1 & 1 & $\mathrm{~L} 1 \mathrm{P} 01$ \\
\hline 2 & 0 & $\mathrm{~L} 1 \mathrm{P} 02$ \\
\hline 3 & 0 & $\mathrm{~L} 1 \mathrm{P} 03$ \\
\hline$\ldots$ & $\ldots$ & $\ldots$. \\
\hline 25 & 0 & $\mathrm{~L} 1 \mathrm{P} 25$ \\
\hline 26 & 0 & $\mathrm{~L} 1 \mathrm{P} 26$ \\
\hline
\end{tabular}

Gambar 17. Terisi_kosong ter-update

2) Pengujian Fungsionalitas Lot Parkir

Pengujian prototipe lot parkir dilakukan untuk menguji keberhasilan prototipe mengirim dan menerima data dari sensor ke aplikasi monitoring perparkiran. Prototipe lot parkir di pasang di tiap-tiap lot perparkiran yang dapat di lihat pada Gambar 18.

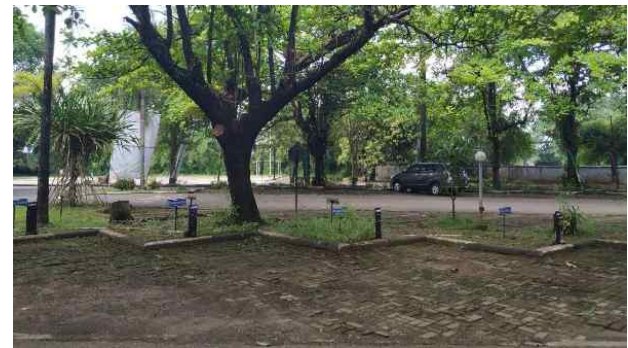

Gambar 18. Prototipe Lot Parkir

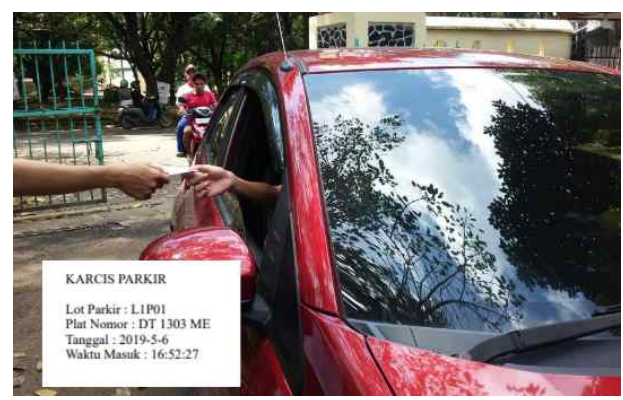

Gambar 19. Pemberian Kartu Parkir

Pada Gambar 19 admin memberikan kartu parkir ke pemilik kendaraan dimana admin memilih lot parkir yang terdekat yaitu L1P01 dan memasukkan nomor plat kendaraan pengguna dan lot parkir pada tampilan monitoring perparkiran yang dapat dilihat pada Gambar 15 berubah menjadi warna kuning.

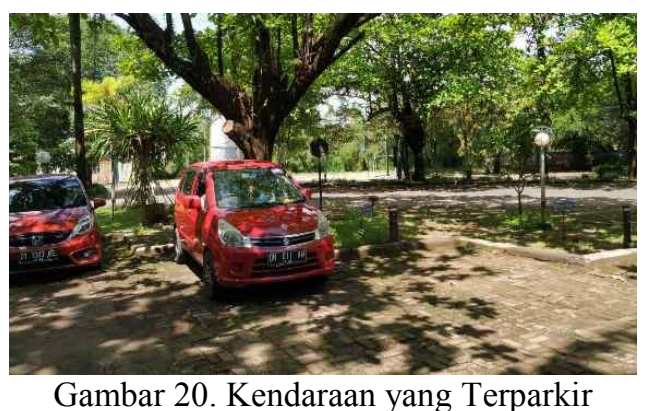

Pada Gambar 20 terdapat kendaraan yang terparkir, kendaraan dengan nomor plat DT 1303 ME berada pada lot parkir L1P01, sedangkan kendaraan dengan nomor plat DN 611 AW memarkirkan kendaraanya pada lot parkir L1P02. Pada tampilan monitoring perparkiran lot L1P01 dan lot L1P02 berwarna merah yang berarti lot terisi dapat dilihat pada Gambar 21.

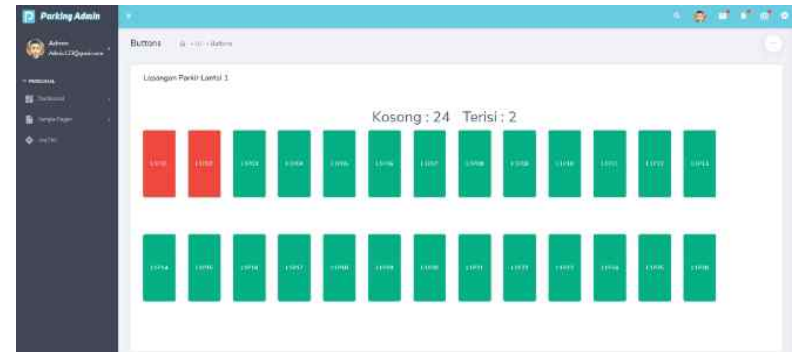

Gambar 21. Tampilan Monitoring Perparkiran 


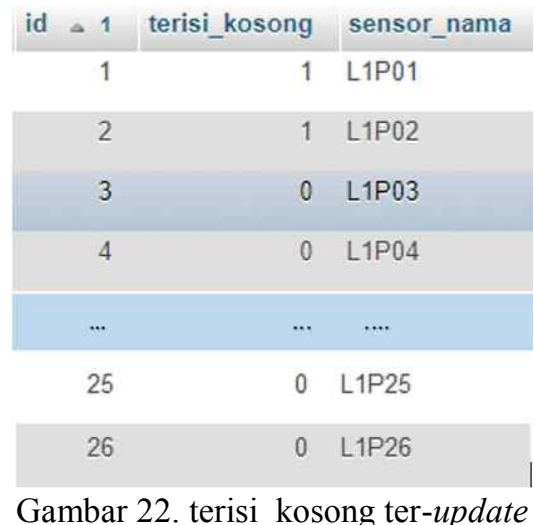

Pada Gambar 22 Ketika sensor mendeteksi kendaraan pada lot parkir maka pada tabel sensor kolom terisi_kosong di database ter-update dengan angka "1" yang dapat dilihat pada Gambar 22 berarti lot parkir L1P01 dan L1P02 telah terisi kendaraan maka informasi pengguna perparkiran masuk ke database sistem seperti yang tampil pada Gambar 23.

$$
\begin{aligned}
\text { id }-1 \text { lot plat datetime } \\
1 \text { L1P01 DD 1303 ME 2019-05-19 14:35:32 } \\
2 \text { LIP02 DN 611 AW 2019-05-19 14:36:55 } \\
\text { Gambar 23. tabel_log ter-update }
\end{aligned}
$$

3) Pengujian Fungsionalitas Lot Parkir

Jika dilihat secara keseluruhan pengujian fungsionalitas maka menghasilkan data pada tabel 1 .

Tabel 1 Pengujian Fungsionalitas Lot Parkir

\begin{tabular}{|c|c|c|c|c|}
\hline $\begin{array}{c}\text { Skenario } \\
\text { Pengujian }\end{array}$ & $\begin{array}{c}\text { Lot parkir } \\
\text { berwana } \\
\text { Hijau }\end{array}$ & $\begin{array}{c}\text { Lot } \\
\text { parkir } \\
\text { berwarna } \\
\text { kuning }\end{array}$ & $\begin{array}{c}\text { Lot } \\
\text { parkir } \\
\text { berwarna } \\
\text { merah }\end{array}$ & Ket. \\
\hline $\begin{array}{c}\text { Pengguna } \\
\text { menuggu di portal }\end{array}$ & Ya & Tidak & Tidak & Berhasil \\
\hline $\begin{array}{c}\text { Pengguna } \\
\text { Mendapatkan kartu } \\
\text { parkir }\end{array}$ & Tidak & Ya & Tidak & Berhasil \\
\hline $\begin{array}{c}\text { Pengguna } \\
\text { Memarkirkan } \\
\text { kendaraan di lot }\end{array}$ & Tidak & Tidak & Ya & Berhasil \\
\hline $\begin{array}{c}\text { Pengguna } \\
\text { meninggalkan lot } \\
\text { parkir }\end{array}$ & Ya & Tidak & Tidak & Berhasil \\
\hline
\end{tabular}

\section{Pengujian Kinerja}

Pengujian kinerja dilakukan untuk menguji sistem monitoring perparkiran menggunakan sensor ultrasonik PING berbasis wireless yang meliputi pengujian waktu respon perubahan warna lot.

1) Pengujian Waktu Respon Perubahan Warna Lot

Pengujian ini dilakukan untuk menguji kecepatan respon sensor dan mengirim data ke database, pengujian dilakukan sebanyak 10 kali dengan jarak sensor yang berbeda-beda dan jarak mundur mobil ke lot parkir sama dengan $4 \mathrm{~cm}$. Pengujian waktu dimulai pada saat mobil mundur ke lot parkiran. Adapun hasil pengujian tersebut dapat dilihat pada tabel 2 .

Tabel 2 Pengujian Waktu Respon Perubahan Warna Lot

\begin{tabular}{|c|c|c|}
\hline No.Pengujian & $\begin{array}{c}\text { Jarak } \\
\text { Sensor(cm) }\end{array}$ & $\begin{array}{c}\text { Kecepatan Waktu } \\
\text { Respon(s) }\end{array}$ \\
\hline 1 & 40 & 16.88 \\
\hline 2 & 60 & 15.20 \\
\hline 3 & 80 & 14.06 \\
\hline 4 & 100 & 13.04 \\
\hline 5 & 120 & 11.19 \\
\hline 6 & 140 & 09.56 \\
\hline 7 & 160 & 08.16 \\
\hline 8 & 180 & 05.56 \\
\hline 9 & 200 & 05.26 \\
\hline 10 & 220 & 05.03 \\
\hline
\end{tabular}

Dari hasil pengujian waktu respon perubahan warna lot pada sensor, digambarkan dalam bentuk grafik seperti pada Gambar 24.

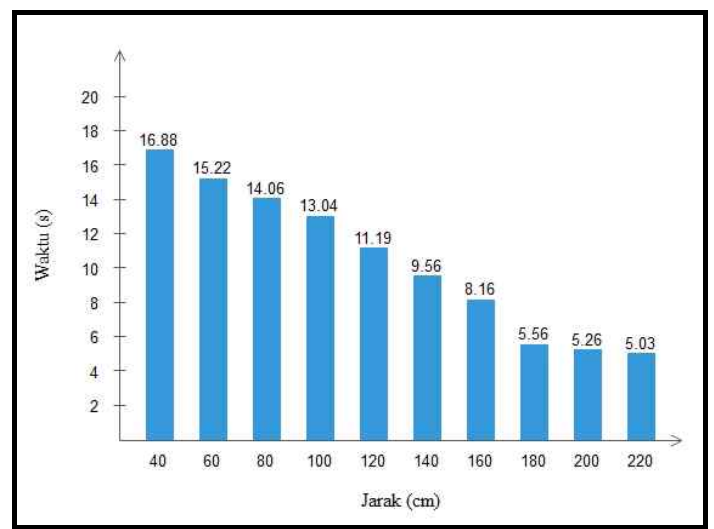

Gambar 24. Grafik Waktu Respon Perubahan Warna Lot

Dari grafik pada Gambar 24 menunjukkan bahwa jarak sensor terhadap kendaraan berpengaruh pada waktu respon. Dari hasil pengujian pada Gambar 24 juga terlihat bahwa semakin jauh jarak deteksi sensor maka semakin cepat waktu perubahan warna lot pada tampilan monitoring perparkiran. Dari hasil pengujian tersebut dapat dikatakan bahwa jarak sensor dengan $180 \mathrm{~cm}$ dengan kecepatan waktu respon 5.56 detik, $200 \mathrm{~cm}$ dengan kecepatan waktu respon 5.26 detik, dan $220 \mathrm{~cm}$ dengan kecepatan waktu respon 5.03 detik. Jika ketiga hasil tersebut di rata-ratakan maka di peroleh angka 5.28 detik waktu respon, nilai waktu respon tersebut merupakan nilai terbaik sensor ultrasonik untuk mendeteksi kendaraan.

\section{v. Kesimpulan}

Berdasarkan hasil pengujian pada penelitian ini dapat disimpulkan bahwa:

1. Sistem monitoring yang dibangun dapat melakukan monitoring perparkiran dan 
mengetahui jumlah lot parkir pada area parkiran yang kosong maupun lot parkir yang sedang terisi oleh kendaraan.

2. Sistem monitoring yang telah dibangun mampu memberikan informasi terhadap ketersediaan lot parkir yang kosong dan terintegrasi database untuk menyimpan informasi pemilik kendaraan berdasarkan kartu parkir. Informasi pada kartu parkir yaitu lot parkir, plat nomor kendaraan, tanggal masuk, dan waktu masuk.

3. Hasil pengujian menunjukkan semakin jauh jarak deteksi sensor maka semakin cepat waktu respon perubahan warna lot pada tampilan monitoring perparkiran. Sensor dengan jarak $180 \mathrm{~cm}$ dengan kecepatan waktu respon 5.56 detik merupakan nilai terbaik sensor ultrasonik PING untuk mendeteksi kendaraan.

\section{Ucapan Terima Kasih}

Penulis mengucapkan terima kasih kepada Allah Subhanahu Wa Ta'ala, kepada seluruh dosen prodi Teknik Komputer dan Jaringan PNUP, terkhusus kepada orang tua saudara Youri Putra Peradana serta kerabat yang telah mendukung penyelesaian pendidikanya di Politeknik Negeri Ujung Pandang.

\section{Daftar Pustaka}

[1] Badan Pusat Statistik, "Perkembangan Jumlah Kendaraan Bermotor Menurut Jenis 1949-2017" 2016. [Online]. Available: https://www.bps.go.id/linkTableDinamis/view/id/1133. [Accessed: 06-Nov-2018].

[2] Detik.com, "Warga Keluhkan Sulitnya Cari Parkiran Mobil di Mal-Mal Jakarta", 2013. [Online]. Available: https://news.detik.com/berita/2358138/warga-keluhkansulitnya-cari-parkiran-mobil-di-mal-mal-jakarta. [Accessed: 06Nov-2018].

[3] A. D. Limantara, Y. Cahyo Setianto Purnomo, and S. W. Mudjanarko, "Pemodelan Sistem Pelacakan Lot Parkir Kosong Berbasis Sensor Ultrasonic Dan Internet Of Things ( Iot ) Pada Lahan Parkir Diluar Jalan," Seminar Nasional Sains dan Teknologi (SEMNASTEK) 2017, pp. 1-2, 2017.

[4] Rudi, I. Dinata, and R. Kurniawan, "Rancang Bangun Protorype Sistem Smart Parking Berbasis Arduino dan Pemantauan Melalui Smartphone," J. Ecotipe, vol. 4, no. 2, pp. 14-20, 2017.

[5] G. T. Mardiani, "Sistem Monitoring Data Aset dan Inventaris PT Telkom Cianjur Berbasis Web," J. Ilm. Komput. dan Inform., vol. 2, no. 1, pp. 35-40, 2013.

[6] J. Martadipura, "Perancangan Sistem Infomasi Perparkiran pada Universitas Komputer Indonesia,” pp. 1-41, 2013.

[7] R. F. H. Putra, K. M. Lhaksmana, and D. Adytia, "Aplikasi IoT untuk Rumah Pintar dengan Fitur Prediksi Cuaca," $e$ Proceeding Eng., vol. 5, no. 1, pp. 1746-1760, 2018.

[8] U. M. Arief, "Pengujian Sensor Ultrasonik PING untuk Pengukuran Level Ketinggian dan Volume Air," J. Ilm. “Elektrikal Enjiniring” UNHAS, vol. 09, no. 02, pp. 72-77, 2011.

[9] Muhammad. G.A., D, Nur., Syahrir, "Aplikasi Sistem Keamanan Gerbang Parkir Politeknik Negeri Ujung Pandang Berbasis Android", Seminar Nasional Teknik Elektro dan Informatika (SNTEI) 2017, pp. 7-12, 2017

[10] Ppatierno, "Message Flow", 2013, [Online]. Available: http://www.embedded101.com/Develop-M2M-IoT-DevicesEbook/DevelopM2MIoTDevicesContent/smid/946/ArticleID/2 24 [Accessed: 6-Nov-2018]. 